\title{
GUARANTEE PRODUCT PORTFOLIO: PERFORMANCE AND OPTIMAL PORTFOLIO
}

\author{
ANALYSIS \\ Santosa ${ }^{1}$, Noer Azam Achsani ${ }^{2}$, Hendro Sasongko ${ }^{3}$ \\ ${ }^{1,2}$ School of Business, IPB University, Bogor, Indonesia \\ ${ }^{3}$ Faculty of Economics, Pakuan University, Bogor, Indonesia \\ Email: santosa_88@yahoo.com
}

\begin{abstract}
This study aims to analyze the performance of guarantee products and optimize guarantee portfolio at PT Penjaminan ABC. The method used in forming the optimal guarantee portfolio is the Markowitz method and the single index model. The results of the formation of optimal portfolios based on the Markowitz method show that there are five eligible guarantee products included in the optimal guarantee portfolio, namely construction financing, counter bank, general financing, micro financing, and multi-use financing. While custom bond, surety bonds, and other guarantees are not included in the optimal portfolio. In contrast to the Markowitz method, based on the single index model, all guarantee products are not eligible to be included in the optimal guarantee portfolio. Managerial implications of the optimal guarantee product portfolio is an increase in guarantee returns which will further increase company profits and increase company equity. An increase in company equity will reduce the gearing ratio in order to comply with regulations, because the gearing ratio is calculated by dividing the outstanding guarantee volume by the total equity.
\end{abstract}

Keywords: risk, return, optimal guarantee portfolio

\section{ARTICLE INFORMATIONS}

Article history: submitted: April 12, 2020; revised: June, 1 2020; accepted: June 11, 2020

JEL Classifiction: G11

How to cited: Santosa, et al. (2020). Guarantee Product Portfolio: Performance and Optimal Portfolio Analysis. JIMFE (Jurnal IImiah Manajemen Fakultas Ekonomi), 6(1), 43-58.

https://doi.org/10.34203/jimfe.v6i1.1928

Copyright@2020. JIMFE (Jurnal IImiah Manajemen Fakultas Ekonomi) Universitas Pakuan

\section{INTRODUCTION}

Businessmen that classified as Micro, Small, and Medium Enterprises (MSME) have a huge role in sustaining the national economy. However, the empowerment of MSMEs faces many obstacles, including accessing credit from banks, especially because MSMEs are unable to meet collateral requirements. The Guarantee Company assists MSMEs by acting as guarantors for debtors to banks. Guarantee is the activity of providing guarantees by the Guarantor for the fulfillment of Guaranteed financial obligations to the Recipient of the Guarantee.

In running its business, the guarantee capacity of a guarantee company is limited by the gearing ratio, which is the ratio between the guaranteed volume of the guarantee and its amount equity. In accordance with Financial Service Authority (OJK) regulations, the maximum gearing ratio is 40 times. Based on the results of management studies in 2017, the gearing ratio at the end of 2018 is projected at 38,07 times and at the end of 2019 at 42,85 times. This means that the gearing ratio in 2019 will violate applicable regulations. Based on this study, management submitted a request to shareholders to increase the paid-in capital of Rp50 billion. With this additional paid-in capital, the gearing ratio in 2018 will be 32,48 times and in 2019 it will be 36,95 times. The increase in paid-up capital in 2018 is not in accordance with the plans set out in the company's Long-Term Plan 2015-2019. In the 
company's long-term plan, there is no additional paid-up capital until 2019.

The need for additional paid-in capital to maintain the gearing ratio, which is not listed in the company's long-term plan indicates that the guarantee portfolio is not optimal. In order to ensure that the company can achieve its objectives according to the target and operate within the allowed guarantee capacity, it is necessary to form an optimal guarantee portfolio, considering the risk and return factors. Many studies on optimizing investment portfolios with the Markowitz model and the single index model, for example, Febri Eka Saputra (2004) conducted research on the portfolio strategy of agribusiness issuers on the Jakarta stock exchange using the Markowitz approach. Optimal stock composition according to the results of the study are Astra Agro Lestari $26.00 \%$, Indofood $7.21 \%$, Gudang Garam 46.72\%, and Bentoel 20.07\%. While Defri and Dzulkirom (2017) analyzed the formation of the company's stock portfolio of the Sri Kehati-IDX index using a single index model, with the conclusion that of the 19 shares analyzed, there were 12 shares that had a positive expected return and 7 shares that had a negative expected return.

Research on the optimal portfolio of guarantee products needs to be done because the guarantee activity is different from other investment activities, such as bank credit or investment in the capital market. For example, in bank loans, banks lend funds to debtors and get interest. While investing in the capital market, investors spend funds to buy investment instruments hoping to get returns in the form of dividends, capital gains, or other returns. While in the guarantee business, the guarantor company does not spend money at the time of guarantee. Returns are obtained in the form of compensation services and risks derived from claims incurred. Therefore, research on the guarantee portfolio needs to be done.

\section{LITERATURE REVIEW}

Investment is one of the three main functions of financial management, in addition to financing and asset management. Investment is the placement of current funds by expecting future financial benefits. There are various kinds of investment instruments in financial assets in the money market, capital market, and derivatives market. Each investment instrument has different characteristics, both in return and risk.

In general, investments with high returns will be accompanied by high risks. In other words, investors are willing to pay a higher price if they have a higher expectation of return. This is where the risk-return trade-off occurs (Bodie and Kane, 2014). Because of the trade-off between risk and return it is necessary to diversify investments that produce an investment portfolio. Portfolio, which is a collection of several investment assets / instruments. The purpose of an investment portfolio is to maximize returns or minimize the risk of investment activities.

Modern portfolio theory (MPT) is a theory of how risk-averse investors can build portfolios to optimize or maximize expected returns at certain market risk levels, emphasizing that risk is an inherent part of profit. According to the theory, it is possible to build an efficient frontier from an optimal portfolio that offers maximum expected return at a certain level of risk. This theory was pioneered by Harry Markowitz in his Portfolio Selection paper, published in 1952 by the Journal of Finance. He was later awarded the Nobel Prize for developing MPT.

Hartono (2013) suggested that the formation of an optimal portfolio with the Markowitz model approach was carried out by analyzing the relationship between risk and expected return. Risk is measured by the standard deviation or variance, while the expected return is determined by the average return. Therefore, this approach with the Markowitz model is also called the mean variance method. 
Many researches have been done on optimal portfolios in the capital market and in the loan portfolio. However, there has not yet been any research on optimal portfolio in the guarantee sector. Research on the optimal portfolio in the guarantee sector needs to be done because the guarantee activity has different characteristics from credit activities and investment activities in the capital market. In credit activities, banks channel funds to debtors. Likewise in capital market activities, investors spend funds to buy shares or other investment instruments. While the guarantee activity, the guarantor company does not spend funds at the time of guarantee. Therefore, research on the guarantee portfolio needs to be done.

As a guarantee company, PT Penjaminan $A B C$ is required to operate sustainably, generate profits on target, and operate in accordance with applicable regulations. The profit target according to company's long-term plan is not achieved, the projected gearing ratio in 2019 will exceed 40 times, which means it exceeds the maximum allowable provisions, so that it requires additional capital in 2018, indicating that the guarantee portfolio is not optimal and an analysis of portfolio performance is needed guarantees applied. Measurement of the performance of the guarantee portfolio is done by Sharpe ratio, Treynor ratio, and alpha Jensen.

Performance measurement with Sharpe ratio is done by measuring the difference in the rate of return of the portfolio reduced by the risk free rate, then dividing the results by the risk of rate of return, which is the standard deviation of the portfolio's rate of return. The greater the Sharpe ratio, the better the investment performance.

Almost the same as the Sharpe ratio method, portfolio performance measurement with Treynor ratio is done by calculating the difference between the portfolio's rate of return and the risk-free rate. Then the difference is divided by investment beta, which is a systematic risk to the investment in question. The greater the Treynor ratio value, the better the investment performance.

While the measurement of investment performance with Alpha Jensen is done by comparing the portfolio rate of return with the rate of return calculated based on the capital asset pricing model (CAPM). If the alpha value is positive it means that the investment has good performance, and vice versa.

Furthermore, the guarantee portfolio of PT Penjaminan $A B C$ will be optimized by using the Markowitz method and single index model. In Markowitz's theory, research is conducted by examining returns, standard deviations, variances, covariance, and correlations of each guarantee product. Furthermore, optimal portfolio formulation will be carried out using the Markowitz approach, minimizing portfolio risk to obtain a certain level of return.

In the single index model approach, portfolio optimization starts with calculating the excess return of the guarantee portfolio, which reduces the rate of return of the portfolio by risk-free rate. The next step is to calculate excess return to beta (ERB), which is dividing excess return by beta. The next step is to calculate the cut-off rate and determine the cut-off point. The cut-off point is the limiting point between investment instruments that are feasible in the optimal portfolio and those that are not feasible. Investment instruments that have ERB value greater than the cut-off point are eligible to be included in the portfolio and vice versa. The next step is to determine the portion of each guarantee product in the optimal portfolio. Based on the results of performance analysis and optimization of the guarantee portfolio, it can be seen the managerial implications of this study.

\section{RESEARCH METHOD}

This research is a case study of PT Penjaminan $A B C$. The data used in this study are secondary data from internal PT Penjaminan ABC. The data used are data about guarantee products in 
the period of January 1, 2015 to December 31, 2018. Data processing and analysis are carried out in three stages, namely the review of the historical guarantee portfolio, the measurement of the performance of the historical guarantee portfolio, and the establishment of an optimal guarantee portfolio.

\section{Analysis of Historical Guarantee Portfolio}

Calculation of Product Guarantee Returns Calculation of expected returns for each guarantee product is done by calculating the guarantee services fee of a guarantee product against the allocation of guarantee products. The formula to calculate expected return according to Markowitz (1952):

$$
\mathrm{Ei}=\sum_{\mathrm{i}=1}^{\mathrm{N}} \mathrm{Xi} \mu \mathrm{i}
$$

Explanation:

$\mathrm{Ei}=$ Expected return from asset $\mathrm{i}$

$X_{i}=$ Percentage of assets allocated to investments i

$\mu_{\mathrm{i}}=$ Expected return from investment $\mathrm{i}$

$\mathrm{N}=$ Number of types of investment

Calculation of Product Guarantee Risk

Guarantee risk is measured by Variance and Standard Deviation. The formula used to calculate the standard deviation according to Markowitz (1952):

Variance:

$$
\mathrm{Vi}=\sum_{\mathrm{i}=1}^{\mathrm{N}} \sum_{\mathrm{j}=1}^{\mathrm{N}} \sigma \mathrm{ijXiXj}
$$

Explanation:

$\sigma i j=$ covariance between returns from assets $i$ and $j$

With notes: $\sum_{\mathrm{i}=1}^{\mathrm{N}} \mathrm{Xi}=1$ dan $\mathrm{X}_{\mathrm{i}} \geq 0$

Standard Deviation:

$$
\sigma \mathrm{i}=\sqrt{\mathrm{V}} i
$$

Explanation:

$\sigma i=$ Standard deviation return asset $\mathrm{i}$

$\mathrm{Vi}=$ Varians return asset $i$

Covariance of Guarantee Products

Covariance is the tendency of return of an investment instrument to move together with the return of other investment instruments. According to Bodie et.al (2014) covariance is calculated by the following formula:

$$
\begin{aligned}
& \operatorname{Cov}\left(w_{D} r_{D}, w_{E}, r_{B}\right)=E\left\{\left[w_{D} r_{D}-\right.\right. \\
& \left.\left.w_{D} E\left(r_{D}\right)\right]\left[w_{e} r_{E}-w_{E} E\left(r_{E}\right)\right]\right\}
\end{aligned}
$$

Explanation:

$$
\begin{aligned}
& \text { Cov : Covariance between } \\
& \left(w_{D} r_{D}, w_{E}, r_{B}\right) \quad \text { investment instruments } \\
& \text { returns } \mathrm{D} \text { and } \mathrm{E} \\
& \mathrm{w}_{\mathrm{D}}, \mathrm{w}_{\mathrm{E}} \quad \text { : Weight (percentage) of } \\
& \text { investment instruments } \\
& \mathrm{D} \text { and } \mathrm{E} \\
& \mathrm{r}_{\mathrm{D}}, \mathrm{r}_{\mathrm{E}} \quad \text { : Return instruments } D \\
& \text { and } E \\
& \mathrm{E}\left(\mathrm{r}_{\mathrm{D}}\right), \mathrm{E}\left(\mathrm{r}_{\mathrm{E}}\right) \text { : The expected return } \\
& \text { from investment } \\
& \text { instruments } D \text { and } E
\end{aligned}
$$

Correlation of Guarantee Products

Correlation shows the significance of the relationship between one investment instrument with another. Value correlation (+1) means having a direct and strong relationship. Value correlation (-1) means it has an inverse and strong relationship. A correlation of zero (0) means there is no relationship. The correlation formula according to Bodie et.al (2014) is as follows:

$$
\operatorname{Corr}\left(r_{D}, r_{E}\right)=\frac{\operatorname{Cov}\left(r_{D}, r_{E}\right)}{\sigma_{D} \sigma_{E}}
$$

Explanation:

$\operatorname{Corr}\left(\mathrm{r}_{\mathrm{D}}, \mathrm{r}_{\mathrm{E}}\right)$ : The correlation coefficient between investment instruments returns $D$ and E 


$$
\begin{array}{ll}
\operatorname{Cov}\left(\mathrm{r}_{\mathrm{D}}, \mathrm{r}_{\mathrm{E}}\right): \begin{array}{l}
\text { Covariance between } \\
\text { investment instruments } \\
\end{array} \\
\begin{array}{ll}
\text { returns } \mathrm{D} \text { and } \mathrm{E} \\
\sigma_{\mathrm{D}}, \sigma_{\mathrm{E}}: \text { Standard deviation of }
\end{array}
\end{array}
$$

: Standard deviation of
investment instruments $D$
and $E$

\section{Performance Measurement of Historical Guarantee Portfolio}

The measurement of the performance of the guarantee portfolio is carried out by comparing returns with risk. In this study, portfolio performance measurements using the Sharpe ratio, Treynor ratio, and Jensen ratio. The riskfree rate used in this study is the interest rate of BI 7 Day Repo Rate.

Sharpe ratio

Sharpe ratio is a measurement of the performance of investment portfolios based on a comparison between the return generated and the total portfolio risk. The Sharpe ratio formula according to Bodie et.al. (2014) is as follows:

$$
S=\frac{\bar{r}_{p}-\bar{r}_{f}}{\sigma_{p}}
$$

Explanation:

$S \quad$ : Sharpe ratio

$\bar{r}_{p} \quad$ : Average portfolio return

$\bar{r}_{f} \quad$ : Average return on risk-free assets

$\sigma_{p} \quad$ : Standard deviation of the portfolio

\section{Treynor ratio}

Treynor ratio is also a comparison between the return generated and the risk of the portfolio. However, only comparable risk is systematic risk (market risk), i.e. beta value. Beta is a systematic risk calculated using market return data. Basically, beta is the gradient of the equation between return on assets and market returns. In this study, the market return used is the $\mathrm{BI} 7$ day repo rate. The Treynor ratio formula according to Bodie et.al. (2014) is:

$$
T=\frac{\bar{r}_{p}-\bar{r}_{f}}{\beta_{p}}(7)
$$

Explanation:

$\mathrm{T} \quad$ : Treynor ratio

$\overline{\mathrm{r}}_{\mathrm{p}} \quad$ : Average portfolio return

$\overline{\mathrm{r}}_{\mathrm{f}} \quad$ : Average return of risk-free assets

$\beta_{\mathrm{p}} \quad$ : Portofolio beta

Alpha Jensen

Alpha Jensen is a risk-adjusted return performance measurement that shows whether the average portfolio return of an investment is above or below the capital asset pricing model (CAPM), based on the portfolio beta and the average market return. As in calculating the Treynor ratio, beta at alpha Jensen is a systematic risk calculated using market return data. The formula for calculating alpha Jensen according to Bodie et.al. (2014) is:

Alpha $=\mathrm{R}(\mathrm{i})-(\mathrm{R}(\mathrm{f})+\mathrm{B} \times(\mathrm{R}(\mathrm{m})-\mathrm{R}(\mathrm{f})))$

Explanation:

$R$ (i) = portfolio or investment return

$R(m)=$ return from the market index

$R(f) \quad=$ risk-free rate

$\mathrm{B} \quad=$ beta of an investment portfolio

\section{Optimization of Guarantee Portfolios}

Markowitz Method

The formula for optimizing guarantees is as follows:

Minimum guarantee portfolio variance according to Bodie et.al. (2014):

$$
\begin{gathered}
\sigma p^{2}=\sum_{i=1}^{n} w i^{2} \sigma i^{2}+ \\
\sum_{i=1}^{n} \sum_{j=1}^{n} w i w j \sigma i j
\end{gathered}
$$

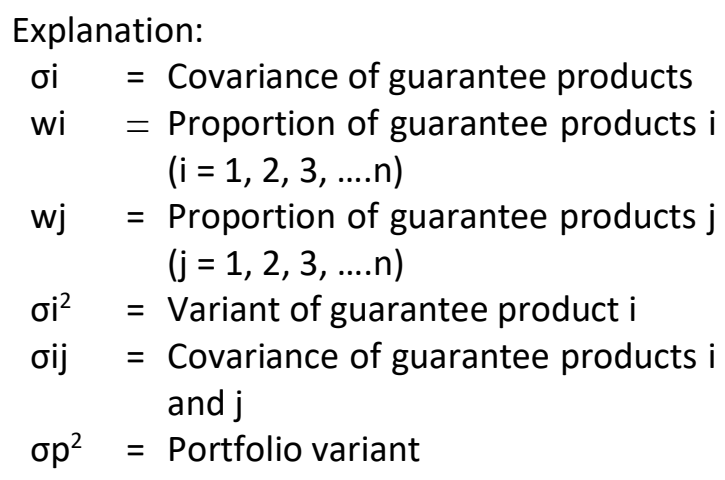


Single Index Model (SIM) Method

Calculate the Excess Return to Beta (ERB)

$E R B$ is obtained by dividing excess return by beta. Excess return is the difference between the return of each investment instrument and the risk- free rate. The ERB formula according to Elton dan Gruber (1995) is as follows:

Explanation:

$$
E R B=\frac{r_{i}-r_{f}}{\beta_{i}}
$$

\section{ERB : Excess Return to Beta}

$r_{i}:$ Expected return for investment instruments i

$r_{f} \quad$ : Return of risk-free asset

$\beta_{i} \quad$ : Beta investment instruments $i$

Determine the cut-off point

Investment instruments that make up the optimal portfolio are investment instruments with ERB values greater than or equal to the ERB value at point $C^{*}$.he cut off rate according to Elton dan Gruber (1995) is calculated using the following formula:

$$
C_{i}=\frac{\sigma^{2}{ }_{m} \sum_{j=1}^{n} \frac{\left(\bar{r}_{j}-r_{f}\right) \beta_{j}}{\sigma^{2} e j}}{1+\sigma_{m}{ }^{2} \sum_{j=1}^{n}\left(\frac{\beta^{2} j}{\sigma^{2} e j}\right)}
$$

Explanation:

$$
\begin{array}{ll}
\mathrm{C}_{\mathrm{i}} & : \text { Cutt-off rate } \\
\sigma^{2}{ }_{m} & : \text { Market variant } \\
\beta_{\mathrm{j}} & : \begin{array}{l}
\text { Beta of all investment } \\
\text { instruments (systematic risk) }
\end{array} \\
\sigma^{2}{ }_{\mathrm{ej}}: \begin{array}{l}
\text { Variance error of all investment } \\
\text { instruments (unsystematic risk) }
\end{array} \\
\bar{r}_{j} \quad: \begin{array}{l}
\text { Return of all investment } \\
\text { instruments }
\end{array} \\
\mathrm{r}_{\mathrm{f}} \quad: \begin{array}{l}
\text { Return of risk-free asset return of } \\
\text { all investment instruments }
\end{array}
\end{array}
$$

Determine the portion of each investment instrument

After selecting investment instruments included in the optimal portfolio, the next step is to determine the portion (percentage) of each investment instrument in the portfolio. The formula for calculating the portion of an investment instrument according to Fischer and Jordan (1999) is as follows:

$$
w_{i}=\frac{Z_{i}}{\sum_{j=1}^{n} Z_{j}}
$$

On condition:

$\sum_{i=1}^{n} w_{i}=1$

Whereas Zi according to Fischer and Jordan (1999) is calculated as follows:

$$
Z_{i}=\frac{\beta_{i}}{\sigma^{2}{ }_{i}}\left[\frac{r-r_{f}}{\beta_{i}}-C *\right]
$$

Explanation:

$\mathrm{w}_{\mathrm{i}}$ : The weight of investment instruments $i$

$\mathrm{Z}_{\mathrm{i}} \quad$ : Scale of weighting of investment instruments $\mathrm{i}$

$\sigma^{2}{ }_{i}$ : Unsystematic risk investment instruments $i$

$\beta_{\mathrm{i}}$ : Systematic risk investment instruments $\mathrm{i}$

$\mathrm{C}^{*}$ : Unique cut-off point

\section{RESULTS AND DISCUSSION}

Composition, Return, and Risk of Guarantees Product

The guarantee products at PT Penjaminan ABC consist of custom bond guarantees, counter bank guarantees, surety bonds, multipurpose financing guarantees, general financing guarantees, construction financing guarantees, micro financing guarantees, and other guarantees. Other guarantees are a combination of several guarantee products, each of which has a relatively small volume.

The composition, expected return, actual return, and risk of each guarantee product in the 2015-2018 period can be seen in table 1 below. 
Table 1. Composition, Expected Return, Actual Return, and Risk of Guarantee Products in 20152018

\begin{tabular}{lrrrr}
\hline \multirow{2}{*}{ Guarantee Product } & Composition & $\begin{array}{c}\text { Expected } \\
\text { Return }\end{array}$ & $\begin{array}{c}\text { Actual } \\
\text { Return }\end{array}$ & \multicolumn{2}{l}{ Risk } \\
\cline { 2 - 5 } & \multicolumn{1}{c}{$(\%)$} & $(\%)$ & \multicolumn{1}{c}{$(\%)$} & $(\%)$ \\
\hline Custom Bonds & 5,39 & 0,24 & 0,23 & 0,10 \\
Counter Bank Guarantees & 26,58 & 1,17 & 1,09 & 0,36 \\
Surety Bonds & 21,78 & 0,38 & 0,35 & 0,13 \\
Multi-use financing & 20,50 & 2,82 & 2,66 & 1,34 \\
General Financing & 7,20 & 3,80 & 3,28 & 1,61 \\
Construction Financing & 1,79 & 1,24 & 1,21 & 0,26 \\
Micro Financing & 4,94 & 1,72 & 1,43 & 0,59 \\
Other Guarantees & 11,82 & 1,20 & 1,07 & 0,84 \\
\hline \multicolumn{1}{c}{ Total/Average } & 100,00 & 1,56 & 1,38 & 0,30 \\
\hline
\end{tabular}

Source: processed data, 2015-2018

From Table 1 it can be seen that the composition of guarantees is dominated by counter bank guarantee guarantees, surety bonds, and multipurpose guarantees. Whereas the expected return and actual return, the largest are general financing guarantees, followed by multipurpose financing guarantees, and micro financing guarantees. The expected average return is $1.56 \%$ and the average actual return is $1.38 \%$. The biggest risk is general financing guarantees, followed by multipurpose financing guarantees, and other guarantees. The average risk is $0.30 \%$.

\section{Covariance and Correlation}

Covariance shows the relationship between one guarantee product with another guarantee product. While the correlation shows how strong the relationship is. Covariance of each guarantee product can be seen in table 2 while the correlation can be seen in table 3 .

Table 2. Covariance between Guarantee Products

\begin{tabular}{|c|c|c|c|c|c|c|c|c|}
\hline Guarantee Product & $\begin{array}{l}\text { Custom } \\
\text { Bonds }\end{array}$ & $\begin{array}{c}\text { Counter } \\
\text { Bank }\end{array}$ & $\begin{array}{l}\text { Surety } \\
\text { Bonds }\end{array}$ & $\begin{array}{c}\text { Multi- } \\
\text { use } \\
\text { Financing }\end{array}$ & $\begin{array}{c}\text { General } \\
\text { Financing }\end{array}$ & $\begin{array}{l}\text { Construction } \\
\text { Financing }\end{array}$ & $\begin{array}{c}\text { Micro } \\
\text { Financing }\end{array}$ & $\begin{array}{c}\text { Other } \\
\text { Guarantee }\end{array}$ \\
\hline $\begin{array}{l}\text { Custom Bonds } \\
\text { Counter Bank }\end{array}$ & 0,0000 & & & & & & & \\
\hline Guarantees & 0,0000 & 0,0000 & & & & & & \\
\hline Surety Bonds & 0,0000 & 0,0000 & 0,0000 & & & & & \\
\hline Multi-use financing & 0,0000 & 0,0000 & 0,0000 & 0,0002 & & & & \\
\hline General Financing & 0,0000 & 0,0000 & 0,0000 & $-0,0001$ & 0,0003 & & & \\
\hline Construction Financing & 0,0000 & 0,0000 & 0,0000 & 0,0000 & 0,0000 & 0,0000 & & \\
\hline Micro Financing & 0,0000 & 0,0000 & 0,0000 & 0,0000 & 0,0000 & 0,0000 & 0,0000 & \\
\hline Other Guarantees & 0,0000 & 0,0000 & 0,0000 & 0,0000 & 0,0000 & 0,0000 & 0,0000 & 0,0001 \\
\hline
\end{tabular}

Source: processed data, 2015-2018

From Table 2 it can be seen that custom bonds have a positive covariance with counter bank guarantees, multipurpose financing guarantees, general financing guarantees, and 
micro financing guarantees, as well as having a negative relationship with surety bonds, construction guarantees, and other guarantees. Counter bank guarantees have positive covariance with surety bonds, construction guarantees, and other guarantees, as well as having negative covariance with multipurpose financing guarantees, general financing guarantees, and micro financing guarantees. Surety bonds have positive covariance with multipurpose financing guarantees, construction financing guarantees, and other guarantees, as well as having negative covariates with multipurpose financing guarantees and micro financing guarantees. A multipurpose financing guarantee has a positive covariance with construction financing guarantees, and has a negative correlation with general financing guarantees, micro financing guarantees, and other guarantees. General financing guarantees have a positive covariance with micro financing guarantees and have a negative correlation with construction financing guarantees and other guarantees. Construction financing guarantees have a positive correlation with micro financing guarantees and other guarantees. Micro finance guarantees have a negative correlation with other guarantees.

Table 3. Correlations between Guarantee Products

\begin{tabular}{|c|c|c|c|c|c|c|c|c|}
\hline Guarantee Product & $\begin{array}{c}\text { Custom } \\
\text { Bonds }\end{array}$ & $\begin{array}{c}\text { Counter } \\
\text { Bank }\end{array}$ & $\begin{array}{l}\text { Surety } \\
\text { Bonds }\end{array}$ & $\begin{array}{c}\text { Multi- } \\
\text { use } \\
\text { Financing }\end{array}$ & $\begin{array}{c}\text { General } \\
\text { Financing }\end{array}$ & $\begin{array}{l}\text { Construction } \\
\text { Financing }\end{array}$ & $\begin{array}{c}\text { Micro } \\
\text { Financing }\end{array}$ & $\begin{array}{c}\text { Other } \\
\text { Guarantee }\end{array}$ \\
\hline $\begin{array}{l}\text { Custom Bonds } \\
\text { Counter Bank }\end{array}$ & 1,0000 & & & & & & & \\
\hline Guarantees & 0,0943 & 1,0000 & & & & & & \\
\hline Surety Bonds & $-0,1835$ & 0,3662 & 1,0000 & & & & & \\
\hline Multi-use financing & 0,0059 & $-0,0459$ & 0,0879 & 1,0000 & & & & \\
\hline General Financing & 0,1816 & $-0,0402$ & 0,1529 & $-0,3113$ & 1,0000 & & & \\
\hline Construction Financing & $-0,0295$ & 0,3668 & 0,3770 & 0,0716 & $-0,0866$ & 1,0000 & & \\
\hline Micro Financing & $-0,0028$ & 0,4099 & 0,1908 & $-0,0609$ & $-0,0160$ & 0,3504 & 1,0000 & \\
\hline Other Guarantees & 0,2870 & $-0,1876$ & 0,0227 & $-0,2154$ & 0,3527 & 0,0567 & $-0,1249$ & 1,0000 \\
\hline
\end{tabular}

Source: processed data, 2015-2018

From Table 3 can be seen the strength of the relationship between one guarantee product with other guarantee products, both the relationship is positive or negative.

\section{Measurement of Historical Guarantee Performance}

Performance measurements on each guarantee product, in assessing returns and risks, are carried out using the Sharpe ratio, Treynor ratio, and Alpha Jensen methods. In this study, the risk- free rate used as an indicator of performance is the $\mathrm{BI} 7$-day
(Reverse) Repo Rate. Likewise, the rate of return used as benchmarking is also a 7-day (Reverse) Repo Rate.

\section{Sharpe ratio}

Sharpe ratio is a measurement of the performance of investment portfolios based on a comparison between the return generated and the total portfolio risk. The results of performance measurement of guarantee products using Sharpe ratio can be seen in Table 4 below. 
Table 4. Sharpe Ratio of Each Guarantee Product

\begin{tabular}{|c|c|c|}
\hline \multicolumn{3}{|c|}{ Sharpe } \\
\hline Guarantee Product & Ratio & Conclusion \\
\hline General Financing & $-1,56$ & Underperformed \\
\hline Multi-use financing & $-2,29$ & Underperformed \\
\hline Micro Financing & $-5,87$ & Underperformed \\
\hline Other Guarantees & $-5,99$ & Underperformed \\
\hline Construction Financing & $-10,05$ & Underperformed \\
\hline Counter Bank Guarantees & $-13,22$ & Underperformed \\
\hline Surety Bonds & $-41,18$ & Underperformed \\
\hline Custom Bonds & $-54,13$ & Underperformed \\
\hline
\end{tabular}

Source: processed data, 2015-2018

From Table 4 it can be seen that all guarantee products have a negative Sharpe ratio. This happens because the rate of return of all guarantee products is smaller than the risk-free rate.

\section{Treynor ratio}

Treynor ratio is also a comparison between the return generated and the risk of the portfolio. However, only comparable risk is systematic risk (market risk), i.e. beta value. Beta is a systematic risk calculated using market return data. The results of performance measurement of guarantee products using Treynor ratio can be seen in Table 5 below.

Table 5. Treynor Ratio of Each Guarantee Product

\begin{tabular}{|c|c|c|}
\hline \multicolumn{3}{|c|}{ Treynor } \\
\hline Guarantee Product & Ratio & Conclusion \\
\hline Construction Financing & 0,33 & Outperformed \\
\hline General Financing & 0,17 & Outperformed \\
\hline Other Guarantees & 0,15 & Outperformed \\
\hline Micro Financing & 0,14 & Outperformed \\
\hline Multi-use financing & 0,08 & Outperformed \\
\hline Counter Bank Guarantees & $-1,71$ & Underperformed \\
\hline Surety Bonds & $-1,98$ & Underperformed \\
\hline Custom Bonds & $-5,36$ & Underperformed \\
\hline
\end{tabular}

Source: processed data, 2015-2018

From Table 5 it can be seen that custom bond guarantees, counter bank guarantees, and surety bonds have a negative Treynor ratio and other guarantee products have a positive Treynor ratio.

\section{Alpha Jensen}

As in calculating the Treynor ratio, beta at alpha Jensen is a systematic risk calculated using market return data. The results of Jensen's alpha calculation can be seen in table 6 below. 
Table 6. Alpha Jensen for Each Guarantee Product

\begin{tabular}{lrrc}
\hline \multicolumn{1}{c}{ Guarantee Product } & $\begin{array}{c}\text { Return } \\
(1)\end{array}$ & $\begin{array}{r}\text { E(r) CAPM } \\
(\%)\end{array}$ & $\begin{array}{c}\text { Jensen } \\
\text { Ratio } \\
(\%)\end{array}$ \\
\hline General Financing & $(2)$ & $(3)$ & $\begin{array}{c}(4)=(2)- \\
(3)\end{array}$ \\
Multi-use Financing & 3,28 & 5,80 & $-2,52$ \\
Micro Financing & 2,66 & 5,80 & $-3,14$ \\
Construction Financing & 1,43 & 5,80 & $-4,37$ \\
Counter Bank Guarantees & 1,21 & 5,80 & $-4,58$ \\
Other Guarantees & 1,09 & 5,80 & $-4,71$ \\
Surety Bonds & 1,07 & 5,80 & $-4,73$ \\
Custom Bonds & 0,35 & 5,80 & $-5,45$ \\
Source: processed & 0,23 & 5,80 & $-5,56$ \\
\hline
\end{tabular}

Source: processed data, 2015-2018

From the results of measurements using the three methods above, it can be seen that Sharpe ratio and alpha Jensen provide the best performance values for the same three guarantee products, namely general financing guarantees, multipurpose financing guarantees, and micro financing guarantees. Both are different from the results of measurements with Treynor ratio which provides the best performance value of the three guarantee products, which are construction financing guarantees, public financing guarantees, and other guarantees.

\section{Optimization of Guarantee Portfolios Model Markowitz}

The composition of the guarantee product in the optimal guarantee portfolio using the Markowitz model approach can be seen in table 7 below.

Table 7. Optimal Product Composition

\begin{tabular}{lr}
\hline \multicolumn{1}{c}{ Guarantee Product } & \multicolumn{1}{c}{$\begin{array}{c}\text { Composition } \\
(\%)\end{array}$} \\
\hline Construction Financing & 49,24 \\
Counter Bank & \\
Guarantees & 21,69 \\
General Financing & 12,66 \\
Multi-use financing & 9,49 \\
Micro Financing & 6,93 \\
\hline Total & 100,00 \\
\hline Return & 1,93 \\
\hline Risk & 0,83 \\
\hline Source: processed data, 2015-2018
\end{tabular}

From Table 7 it can be seen that the optimal guarantee portfolio consists of five guarantee products. Thus there are three guarantee products in the hitoris portfolio that are not included in the optimal portfolio, namely custom bonds, surety bonds, and other guarantees. This is consistent with the results of research by Benjamin M. Tabak (2010) who 
conducted research on banks in Brazil, which concluded that banks with concentrated credit portfolios, have better performance compared to banks with more diversified credit portfolios. An increase in return and risk in the optimal portfolio compared to the historical portfolio. For optimal portfolios, portfolio returns are $1.93 \%$ while historical portfolio returns are $1.43 \%$. Optimal portfolio risk of $0.83 \%$ while historical portfolio risk of $0.30 \%$.

Optimization of Markowitz's portfolio places five guarantee products in the portfolio, namely general guarantees, multipurpose guarantees, micro guarantees, construction guarantees, and counter bank guarantees. This is consistent with the results of performance measurement guarantee products with the alpha Jensen method. However, there is a slight difference with the results of performance measurement of guarantee products using the
Sharpe ratio and Treynor ratio methods. In Markowitz's optimal portfolio, the counter bank guarantee product is included in the optimal portfolio, while in the Sharpe ratio and Treynor ratio, it does not include the counter bank guarantee product in the five bestperforming guarantee products and instead, includes other guarantee products.

\section{Single Index Model}

In the single index model method, excess rate to beta (ERB), cut-off rate, and cut-off point are calculated. A guarantee product with an ERB value greater than the cut-off point will be included in the optimal portfolio, and vice versa, a guarantee product with an ERB smaller than the cut-off point is not included in the optimal portfolio. ERB calculation results, cutoff rates, and cut-off points, and decisions in the portfolio can be seen in table 8 .

Table 8. Cut off Rates and Unique Cut off Points

\begin{tabular}{lcccc}
\hline \multicolumn{1}{c}{ Guarantee Product } & ERB & $\mathrm{Ci}$ & $\mathrm{C}^{*}$ & Conclusion \\
\hline Custom Bonds & $-5,35$ & 4,78 & 4,78 & No \\
Counter Bank Guarantees & $-1,71$ & 2,03 & 4,78 & No \\
Surety Bonds & $-1,98$ & 2,03 & 4,78 & No \\
Multi-use financing & 0,08 & $-0,14$ & 4,78 & No \\
General Financing & 0,16 & $-0,30$ & 4,78 & No \\
Construction Financing & 0,32 & $-0,40$ & 4,78 & No \\
Micro Financing & 0,13 & $-0,17$ & 4,78 & No \\
Other Guarantees & 0,14 & $-0,17$ & 4,78 & No \\
\hline
\end{tabular}

Source: processed data, 2015-2018

From table 8 above it can be seen that all guarantee products have smaller ERB values than the unique cut-off point value, so that based on the Single Index Model approach, all guarantee products are not eligible to be included in the optimal portfolio. This is due to the rate of return of all guarantee products smaller than the risk-free rate of $5.80 \%$.

From these two methods it is known that the Markowitz method can form an optimal portfolio while the single index model method cannot. This is due to the Markowitz method using only the return and risk approach, regardless of the return value and the risk. On the other hand, the single index model method uses risk-free rate as a measurement tool, in addition to return and risk of investment assets. Therefore, in the case that all investments have returns below the risk-free rate, then the optimal portfolio cannot be formed. 


\section{Analysis of Optimal Portfolio}

Based on the historical portfolio as listed in

Table 1 and the optimal portfolio in Table 7, a comparison of the composition of the guarantee product can be seen in Table 9 below.

Table 9. Comparison of Guarantee Product Compositions

\begin{tabular}{|c|c|c|c|}
\hline \multirow[b]{2}{*}{ Guarantee Product } & \multicolumn{2}{|c|}{ Portfolio } & \multirow{2}{*}{$\begin{array}{c}\text { Increase } \\
\text { (Decrease) } \\
(\%) \\
\end{array}$} \\
\hline & $\begin{array}{c}\text { Markowitz } \\
(\%)\end{array}$ & $\begin{array}{c}\text { Current } \\
(\%)\end{array}$ & \\
\hline Construction Financing & 9,24 & 1,79 & 47,45 \\
\hline Counter Bank Guarantees & 21,69 & 26,58 & $(4,89)$ \\
\hline Micro Financing & 12,66 & 4,94 & 7,72 \\
\hline Multi-use financing & 9,49 & 20,50 & $(11,01)$ \\
\hline General Financing & 6,93 & 7,20 & $(0,27)$ \\
\hline Surety Bonds & - & 21,78 & $(21,78)$ \\
\hline Other Guarantees & - & 11,82 & $(11,82)$ \\
\hline Custom Bonds & - & 5,39 & $(5,39)$ \\
\hline Total & 100 & 100 & 0 \\
\hline Return & 1,93 & 1,38 & 0,55 \\
\hline Risk & 0,83 & 0,3 & 0,53 \\
\hline
\end{tabular}

Source: processed data, 2015-2018

From Table 9 it can be seen that the historical portfolio consists of eight guarantee products, while the optimal portfolio consists of five guarantee products. There are three guarantee products that are not included in the optimal portfolio. Optimal portfolio return to
$1.93 \%$ or up $0.55 \%$ from the historical portfolio return of $1.38 \%$. Optimal portfolio risk to $0.83 \%$ or up $0.53 \%$ from historical portfolio risk of $0.30 \%$. The comparison of nominal returns on optimal portfolios and historical portfolios can be seen in Table 10 below.

Table 10. Comparison of Nominal Return

\begin{tabular}{|c|c|c|c|}
\hline \multirow{3}{*}{ Produk Penjaminan } & \multicolumn{2}{|c|}{ Portfolio } & \multirow{2}{*}{$\begin{array}{c}\text { Increase } \\
\text { (Decrease) }\end{array}$} \\
\hline & Optimal & Historis & \\
\hline & $\begin{array}{c}\text { (Millions } \\
\text { Rp) }\end{array}$ & $\begin{array}{c}\text { (Millions } \\
\mathrm{Rp})\end{array}$ & $\begin{array}{c}\text { (Millions } \\
\text { Rp) }\end{array}$ \\
\hline Construction Financing & 256.419 & 9.319 & 247.100 \\
\hline Counter Bank Guarantees & 101.316 & 124.178 & $(22.862)$ \\
\hline Micro Financing & 77.374 & 30.197 & 47.177 \\
\hline Multi-use financing & 108.171 & 33.736 & (125.565) \\
\hline General Financing & 97.422 & 101.183 & (3.761) \\
\hline Surety Bonds & - & 32.618 & $(32.618)$ \\
\hline Other Guarantees & - & 54.093 & (54.093) \\
\hline Custom Bonds & - & 5.377 & $(5.377)$ \\
\hline Total & 640.701 & 590.701 & 50.000 \\
\hline
\end{tabular}

Source: processed data, 2015-2018 
From Table 10 it can be seen that in the optimal portfolio provides a nominal return of Rp640,701 million or Rp50,000 million greater than the nominal return of the current portfolio. Thus, the Markowitz portfolio has better performance than the current portfolio.

\section{Conclusion}

In the Markowitz's optimal portfolio consists of five guarantee products while the other three products are not included in the optimal portfolio. The five products included in the optimal portfolio are Construction Financing 49.24\%, Counter Bank Guarantees 21.69\%, Micro Financing 12.66\%, Multi-use Financing $9.49 \%$, and General Financing $6.93 \%$. The guarantee product included in Markowitz's optimal portfolio is the same as the results of Jensen's alpha performance measurement. However, there is a slight difference with the results of performance measurement of guarantee products using the Sharpe ratio and Treynor ratio methods. The counter bank guarantee product is included in Markowitz's optimal portfolio but not in the Sharpe ratio and Treynor ratio. On the other hand, other guarantee products are included in the five best guarantees of Sharpe ratio and Treynor ratio, but they are not included in Markowitz's optimal portfolio. The Markowitz's optimal portfolio provides a return of $1.93 \%$ with a risk of $0.83 \%$. While this historical portfolio provides a return of $1.38 \%$ with a risk of $0.30 \%$. This means that the optimal portfolio return is higher by $0.55 \%$ with a higher risk of $0.53 \%$ compared to the historical portfolio. The managerial impact of this study is that optimal portfolio provides a nominal return of Rp640,701 million or Rp50,000 million greater than the nominal return of the current portfolio. Thus, the Markowitz portfolio has better performance than the current portfolio. Management can use Markowitz's optimal portfolio as an alternative, because it gives a higher rate of return than the current portfolio, even with a higher risk.

\section{REFERENCES}

Bodie, Z., Kane, A., \& Marcus, A. J. (2014). Investment (10th ed.). McGraw-Hill Education.

Cahill, K. E., \& Campbell, S. (2004). Basic Investment Theory Explained. Boston College CRR-JTF Working Paper No. 10. https://doi.org/http://dx.doi.org/10.213 9/ssrn.556790

Defri, F. W., \& AR, M. D. (2017). Analisis pembentukan portofolio optimal saham perusahaan Indeks Sri Kehati-BEI Menggunakan Model Indeks Tunggal (2013-2015). Jurnal Administrasi Bisnis, 47(1), 147-156.

Elton, E. J., \& Gruber, M. J. (1995). Modern Portfolio Theory and Investment Analysis.

Elton, E. J., \& Gruber, M. J. (1997). Modern Portfolio Theory, 1950 to Date (March 1997). Journal of Banking \& Finance, 21(11-12), 1743-1759.

Fischer, D. E., \& Jordan, R. J. (1999). Security Analysis and Portfolio Management (6th ed.). Prentice Hall International.

Friend, I., \& Vickers, D. (1965). Portfolio Selection and Investment Performance. The Journal of Finance, $X X(3), 391-415$.

Gitman, L. J. (2000). Principles of Managerial Finance. Eddison Wesley Longman.

Graham, B., \& Zweig, J. (2003). The Intelligent Investor Ajaran-Ajaran Inti dalam Berinvestasi. Pijar Nalar.

Halim, A. (2005). Analisis Investasi (2nd ed.). Salemba Empat.

Hartono, J. (n.d.). Teori Portofolio dan Analisis Investasi (7th ed.). BPFE Yogyakarta.

Ivanova, M., \& Dospatliev, L. (2017). Application of markowitz portfolio optimization on Bulgarian Stock Market from 2013 to 2016. International Journal of Pure and Applied Mathematics, 117(2), 291-307. https://doi.org/10.12732/ijpam.v117i2. 5 
Ivković, Z., Sialm, C., \& Weisbenner, S. (2008). Portfolio Concentration and the Performance of Individual Investors. Journal of Financial and Quantitative Analysis, 43(3), 613-655. https://doi.org/https://doi.org/10.1017 /S0022109000004233

Jones, C. P. (2009). Investments: Analysis and Management (11th ed.). John Wiley \& Sons, Inc.

Kazan, H., \& Uludağ, K. (2014). Credit Portfolio Selection According to Sectors in Risky Environments: Markowitz Practice. Asian Economic and Financial Review, 4(9), 7791.

Linsmeier, T. J. (2000). Value at risk. Financial Analysts Journal, 56(2), 47-67.

Mangram, M. E. (2013). A simplified perspective of the Markowitz portfolio theory. Global Journal of Business Research, 7(1), 59-70.

Markowitz, H. (1952). Portfolio selection. The Journal of Finance, 7(1), 1-6. https://doi.org/https://doi.org/10.1111 /j.1540-6261.1952.tb01525.x

Marling, H., \& Emanuelsson, S. (2012). The Markowitz Portfolio Theory. Http://Www.Smallake.Kr/WpContent/Uploads/2016/04/HannesMarli ng_SaraEmanuelsson_MPT.Pdf, 1-6.

MULLER, H. H. (1988). Modern Portfolio theory: Some main results. ASTIN BULLETIN, 18(2), 127-145.

Omisore, I., Yusuf, M., \& Christopher, N. (2012). The modern portfolio theory as an investment decision tool. Journal of Accounting and Taxation, 4(2), 19-28.

Saputra, F. E. (2004). Strategi potofolio sahamsaham emiten agribisnis pada Bursa Efek Jakarta. Institut Pertanian Bogor.

Sari, F. A., \& Nuzula, N. F. (2017). Pembentukan portofolio optimal dengan model indeks tunggal (studi pada perusahaan property, real estate and building construction yang tercatat di Bursa Efek Indonesia periode 2013-2015). Jurnal Administrasi Bisnis, 45(1), 1-9.
Setiawan, H., Siregar, H., \& Anggraeni, L. (2015). Optimalisasi kinerja portofolio (studi kasus pada dana pensiun pertamina). Jurnal Aplikasi Manajemen, 113(4), 557-566.

Setyoningsih, A. T. (2015). Analisis portofolio optimal dengan single index model untuk meminimumkan risiko bagi investor di Bursa Efek Indonesia (studi pada saham Indeks Kompas 100 periode Februari 2010-Juli 2014). Jurnal Administrasi Bisnis, 23(1), 1-9.

Sharpe, W. F. (1963). A Simplified Model of Portfolio Analysis. Managment Science, 9(2), 277-293.

Sharpe, W. F. (1964). Capital asset prices: A theory of market equilibrium under conditions of risk. Journal of Finance, 19(3), 425-442.

Tabak, B. M., Fazio, D. M., \& Cajueiro, D. O. (2011). The Effects of Loan Portfolio Concentration on Brazilian Banks' Return and Risk. Journal of Banking \& Finance, 35(11), 3065-3076. https://doi.org/https://doi.org/10.1016 /j.jbankfin.2011.04.006

Tandelilin, E. (1999). Gains from international diversification and domestic portfolio in emerging stocks markets: Philippine and Indonesian perspectives. Gadjah Mada International Journal of Business, 1(2), 63-84.

Tandelilin, E. (2010). Portofolio Dan Investasi: Teori Dan Aplikasi. Kanisius.

Vo, D. H., Pham, T. N., Pham, T. T. V., Truong, L. M., \& Nguyen, T. C. (2019). Risk, Return and Portfolio Optimization for Various Industries in the ASEAN Region. Borsa Istanbul Review, 19(2), 132-138. https://doi.org/Show more https://doi.org/10.1016/j.bir.2018.09.0 03

Yasabari, N., \& Dewi, N. K. (2015). Penjaminan Kredit, Mengantar UMKM Mengakses Pembiayaan. PT Alumni.

Yuliani, F., \& Achsani, N. A. (2017). Analisis pembentukan portofolio berbasis risk 
JIMFE (Jurnal Ilmiah Manajemen Fakultas Ekonomi)

https://journal.unpak.ac.id/index.php/jimfe
Vol. 6 No. 1, Juni 2020, Hal. 43-58

P-ISSN: 2502-1400, E-ISSN: 2502-5678

Žilinskij, G. (2015). Investment portfolio rebalancing decision making. European Scientific Journal, 3(1), 61-69.
Islamic Index Periode Juni 2011 - Mei

2016). Jurnal Al-Muzaraáh, 5(2), 134-

145. 
